\title{
Aksi-Independensi PHBS Vs Covid-19 Di KRB Gunung Merapi
}

\author{
Diah Setyawati Dewanti ${ }^{*}$, Romi Bhakti Hartarto ${ }^{2}$, Nabila Nur Fitria $^{3}$, Riyanti Nur Istiqomah ${ }^{4}$ \\ 1,2,3,4 Department of Economics, Faculty of Economics and Business, Universitas Muhammadiyah Yogyakarta, Jalan Brawijaya \\ Kasihan, Bantul \\ Email:ddewanti@umy.ac.id \\ Jalan Brawijaya, Kasihan Bantul, Yogyakarta, 55183 (0274-387656 ext 180) \\ DOI: 10.18196/ppm.39.98
}

\begin{abstract}
Abstrak
Tujuan utama dari pengabdian ini adalah untuk melihat aksi-independensi di Kawasan Rawan Bencana (KRB) Gunung Merapi dalam pengurangan kasus terkonfirmasi Covid-19. Desa Dongkelsari dengan beberapa hunian tetap yang ada disana menjadi area pengabdian ini merupakan area rawan bencana gunung berapi yaitu Gunung Merapi. Pengabdian ini tidak hanya memberikan bantuan untuk dapat mengurangi konfirmasi kasus Covid 19, tapi juga melihat besarnya perubahan perilaku dari warga di sekitar daerah hunian tetap. Tim pelaksana pengabdian telah memberikan bantuan berupa masker kain, sabun cuci tangan, dan handsanitizer pada awal bulan Maret, saat pandemi Covid 19 mulai merebak di Kabupaten Sleman. Setelah beberapa bulan, tim pelaksana melakukan wawancara terstruktur kepada warga secara acak sederhana. Sebanyak 151 keluarga diwawancara untuk melihat perubahan gaya hidup dan juga aksi-independensi warga di Desa Dongkelsari. Pelaksanaan wawancara dilaksanakan pada bulan September 2020 dengan menggunakan protokol kesehatan sesuai anjuran pemerintah. Adanya persepsi dan gaya hidup sehat pada lokasi ini semenjak diberikan bantuan tersebut menjadi penilaian akhir dari program pengabdian ini. Salah satu tolok ukurnya adalah kesadaran dan pengadaan beberapa fasilitas dalam pengurangan kasus Covid 19. Jumlah frekuensi mencuci tangan (94.1\%), menggunakan hand-sanitizer (48.7\%), memakai masker setiap bepergian (81.6\%) dan memberikan jarak dengan orang lain (40.8\%) sering dilakukan selama pandemi Covid-19.
\end{abstract}

Kata Kunci: Kawasan Rawan Bencana (KRB), Covid-19, Aksi-Independensi, Hidup Sehat

\section{Pendahuluan}

Covid-19 mulai merebak sejak tahun 2019 dan ditemukan pertama kali di Wuhan, China. Beberapa peneliti di bidang kesehatan klinis memaparkan karakteristik penyakit ini. Tidak semua yang telah terkonfirmasi Covid-19 mengalami penyakit pernapasan, semua sangat tergantung dengan tingkat imunitas orang (Shi et al. 2020). Corona virus atau Covid-19 telah ditemukan dan dipaparkan pertama kali oleh Tyrell and Bynoe pada tahun 1966 dengan ditemukan awalnya pasien dengan gejala penyakit flu. Covid-19 atau dikenal sebagai SARSCoV-2 merupakan hasil transisi dari hewan ke manusia. Tanda klinis awal penyakit Covid-19 dapat terdeteksi dengan kasus pneumonia. Akan tetapi, kasus terbaru menggambarkan adanya gejala gastrointestinal dan gejala infeksi, terutama pada kasus yang menyerang pada anak-anak. Pada pasien yang bergejala, gejala penyakit Covid-19 terlihat dengan adanya demam, batuk, hidung tersumbat, kelelahan, dan beberapa tanda lain dari infeksi saluran pernapasan bagian atas. Hal ini sangat erat pada gejala pneumonia yang terjadi di minggu kedua atau ketiga (Velavan and Meyer 2020). Di berbagai negara, penanganan Covid-19 menggunakan kombinasi pada aktivitas penahanan dan mitigasi dari peningkatan massif pasien Covid-19 dan mengatur permintaan jumlah kamar pada rumah sakit. Selain itu, melindungi kelompok rentan (termasuk pasien dengan penyakit komorbiditas - penyakit jantung, tekanan darah tinggi, diabetes dan penyakit tidak menular lainnya) menjadi salah satu kegiatan mitigasi dari bencana penyakit menular yaitu Covid-19 (Jernigan 2020).

Banyak menilai pandemi Covid-19 ini sebagai bencana bahkan dianggap menjadi bencana alam. Dampak negatif tidak hanya pada permasalahan kesehatan tapi juga merambah 
pada sektor ekonomi sebagai konsekuensi dari penyebaran virus ini (Lavell, 2020). Lalu apa yang terjadi jika desa dengan karakteristik rawan bencana terhadap suatu bencana alam terkena penyebaran Covid-19 yang juga dinilai sebagai bencana? Dalam hal ini, partisipasi dan keterlibatan masyarakat menjadi hal yang penting. Seperti halnya saat penanganan tsunami dan gempa, pemerintah Indonesia menggunakan media sosial untuk berkomunikasi dan melibatkan masyarakat dalam penanganan bencana. Saat itu twitter adalah media sosial pertama yang digunakan untuk meningkatkan partisipasi masyarakat secara keseluruhan (Chatfield, Scholl, and Brajawidagda 2013). Citizen Engagement through Government Social Media atau disingkat sebagai CEGSM merupakan salah satu program komunikasi yang dikembangkan untuk bisa mengantisipasi krisis dan bencana dengan komunikasi secara langsung dan tidak langsung (Chen et al. 2020). China menggunakan sosial media sebagai tempat komunikasi dalam pencegahan penularan Covid-19, begitu juga dengan Indonesia. Pengetahuan dan kesadaran terhadap bahaya penyakit dapat menentukan perubahan respon pada orang untuk perilaku pencegahan. Peningkatan pengetahuan dan kesadaran ini dapat dibangun dengan adanya komunikasi dan sosial media sebagai pengurang risiko komunikasi (Karasneh et al. 2020).

Pengurangan risiko pada bencana, khususnya penyebaran penularan Covid-19, membutuhkan adanya partisipasi dan atensi masyarakat dalam mendukung kebijakan pemerintah. Di Provinsi Daerah Istimewa Yogyakarta memaparkan adanya 4M dan 1TM menjadi protokol kesehatan yang harus dilaksanakan setiap individu. Mencuci tangan; Menggunakan Masker: Menjaga jarak; Menghindari kerumunan dan Tidak Merokok merupakan protokol kesehatan pencegahan penularan Covid-19. Partisipasi dan perubahan perilaku menjadi program yang paling efektif dan efisien, maka penelitian ini menganalisa secara deskriptif pengetahuan dan perilaku masyarakat yang bertempat tinggal di Kawasan Rawan Bencana Gunung Merapi.

\section{Metode Pelaksanaan}

Program pengabdian ini merupakan program lanjutan dari penelitian pada tahun sebelumnya yang dilakukan di Hunian Tetap (huntap) Desa Dongkelsari dan Wukirsari, di mana kedua huntap tersebut merupakan Kawasan Rawan Bencana (KRB) II, perbatasan dengan KRB III yaitu zona merah dari Gunung Merapi. Tujuan umum program pengabdian ini adalah pengubahan gaya hidup sehat di KRB II Gunung Merapi, sehingga awal pelaksanaan kegiatan dimulai dengan need assessment gaya hidup warga di huntap Dongkelsari dan Wukirsari. Penilaian awal dilakukan dengan mewawancara Kepala Desa Huntap Dongkelsari mengenai keadaan dan kondisi di tempat pengabdian. Selain itu, penilaian awal atau need assessment dilakukan berdasarkan hasil penelitian yang dilakukan di lokasi yang sama pada tahun lalu. Saat pandemi Covid-19, beberapa gaya hidup warga harus berubah seiring dengan beberapa peraturan yang dikeluarkan oleh Kepala Desa Huntap Dongkelsari serta aksi semi lock-down sejak bulan Maret 2020. Akan tetapi, beberapa warga masih belum mengerti pentingnya 3M yang sudah dikenalkan oleh pemerintah untuk mencegah penularan Covid-19. Salah satu alasan yang dipaparkan oleh warga adalah sulitnya untuk mendapatkan masker, sabun cuci tangan dan handsanitizer pada awal bulan saat pandemi Covid-19 mulai meningkat. Oleh karena itu, bantuan sabun cuci tangan, masker dan handsanitizer diberikan kepada warga huntap Desa Dongkelsari. Pada bulan Maret itu juga, erupsi Gunung Merapi mulai meningkat, sehingga bantuan masker tidak hanya untuk pencegahan Covid-19 tetapi pengurangan risiko dari hujan abu. 


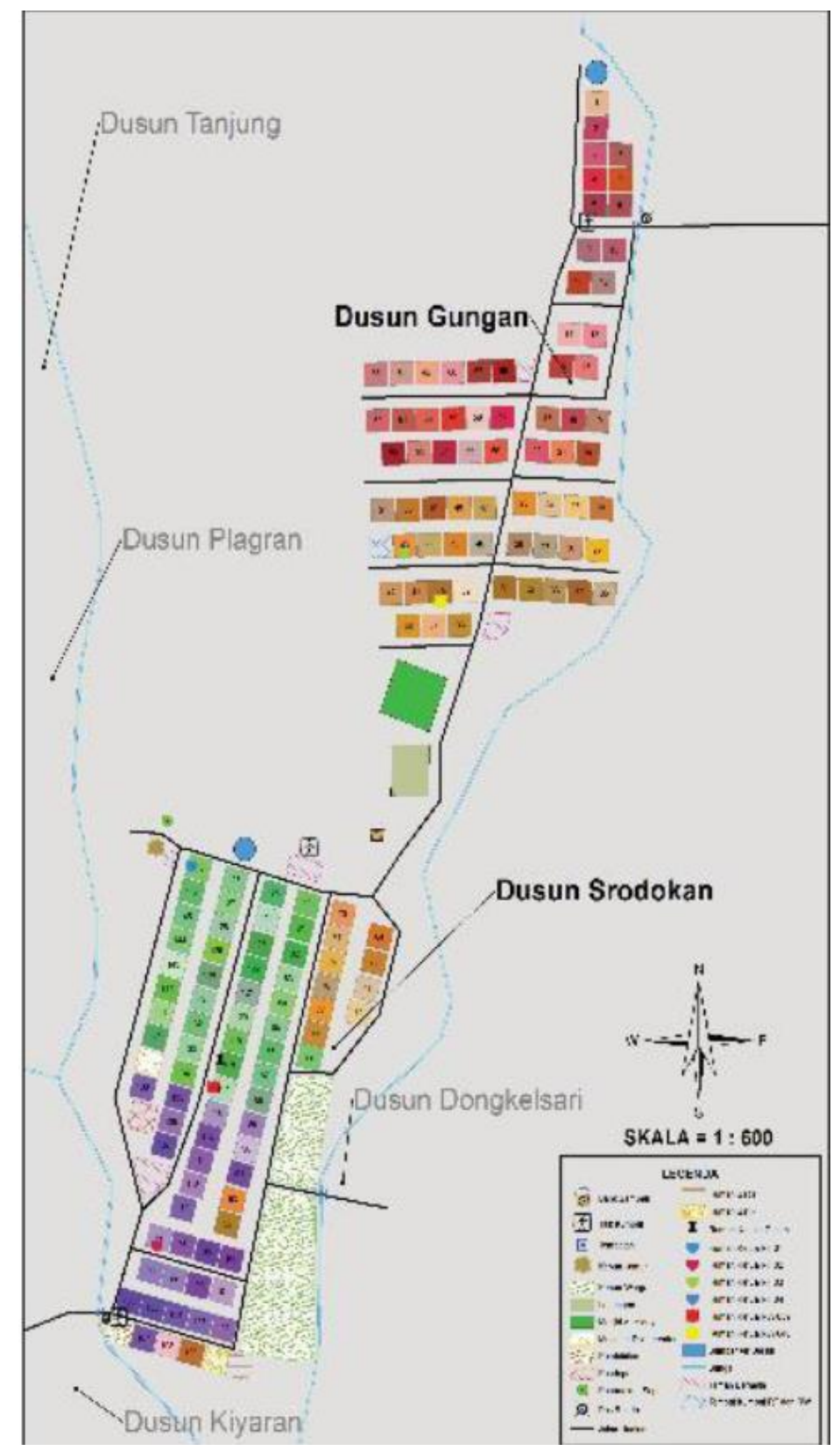

Gambar 1. Peta Wilayah Hunian Tetap Dongkelasari (Kegiatan et al. 2013).

Desa Dongkelsari terdiri dari Dusun Srodokan, Gungan, dan Dongkelsari (lihat Gambar 1). Berdasarkan peta wilayahnya, Huntap Dongkelsari terbagi menjadi dua lokasi di sisi utara dan selatan. Pintu akses masuk berada di antara dua lokasi tersebut. Proses pelaksanaan program pengabdian dimulai dengan pemberian bantuan kepada warga Desa Dongkelsari. Setelah bantuan diberikan kepada 151 keluarga di huntap Desa Dongkelsari dan Wukirsari, bulan Oktober tim mengambil data tentang perubahan persepsi dan perilaku dari warga mengenai perilaku hidup sehat dan bersih mencegah penularan Covid-19. Pengambilan responden dikhususkan pada warga yang berada satu lokasi di Desa Dongkelsari menggunakan angket dan metode wawancara. Data yang sudah ada dianalisa menggunakan analisa univariate dan bivariate. Analisis univariate menggunakan analisis deskriptif dan frekuensi, sedangkan analisis bivariate menggunakan crosstabulasi untuk melihat perilaku hidup bersih dan sehat dalam upaya pencegahan penularan Covid-19 di keluarga masing-masing. 
Tabel 1. Variabel Persepsi dan PHBS Mencegah Penularan Covid-19

\begin{tabular}{|c|c|c|}
\hline No & Variabel & Definisi Operasional variable \\
\hline 1 & Huntap & Variabel huntap merupakan lokasi area tempat tinggal responden \\
\hline 2 & Gender & Jenis kelamin responden yang mewakili unit analisis (yaitu keluarga) \\
\hline 3 & Hidup_Bersih & $\begin{array}{l}\text { Variabel yang menjelaskan tentang frekuensi perilaku hidup bersih dimulai dari: } \\
\text { 1. Cuci tangan dengan sabun dan air } \\
\text { 2. Menggunakan handsanitizer } \\
\text { 3. Menggunakan masker } \\
\text { 4. Menjaga jarak } 1 \text { meter dengan orang lain }\end{array}$ \\
\hline 4 & $\begin{array}{l}\text { Implementasi_Pihak } \\
\text { Luar }\end{array}$ & $\begin{array}{l}\text { Variabel "Implementasi_Pihak Luar" merupakan variabel untuk penilaian implementasi } \\
\text { prosedur 3M berdasarkan penilaian warga Dongkelsari di sekitar lingkungan mereka. } \\
\text { Penilaian implementasi prosedur protokol Kesehatan adalah sebagai berikut: } \\
\text { 1. Penyediaan tempat cuci tangan di depan akses masuk Pasar, Warung makan, Mall } \\
\quad \text { (yang pernah dikunjungi), rumah sakit, klinik, puskesmas, supermarket, sekolah. } \\
\text { 2. Penyediaan hand sanitizer dan tissue di depan akses masuk Pasar, Warung makan, } \\
\quad \text { Mall (yang pernah dikunjungi), rumah sakit, klinik, puskesmas, supermarket, sekolah. }\end{array}$ \\
\hline 5 & Implementasi_Internal & $\begin{array}{l}\text { Variabel penilaian implementasi prosedur 3M dan aksi-independensi Desa Dongkelsari } \\
\text { dalam pencegahan penularan Covid-19 dengan indicator sebagai berikut: } \\
\text { 1. Penyediaan tong cuci tangan di depan rumah } \\
\text { 2. Pembatasan tamu dari luar masuk ke wilayah desa } \\
\text { 3. Pembatasan waktu malam di desa dengan batas maksimal tertentu } \\
\text { 4. Pelarangan tamu luar kota menginap di rumah warga } \\
\text { 5. Buka tutup gerbang desa selama pandemi Covid } 19 \\
\text { 6. } \quad \text { Isolasi mandiri bagi warga setelah bepergian dari luar kota } \\
\text { 7. } \quad \text { Wajib menggunakan masker selama keluar rumah dan di sekitar desa } \\
\text { 8. } \quad \text { Larangan mengadakan hajatan selama pandemi Covid } 19 \\
\text { 9. } \quad \text { Ketentuan lapor diri lebih ketat kepada Ketua RT dan atau Ketua RW }\end{array}$ \\
\hline 6 & Perilaku_PHBS & $\begin{array}{l}\text { Variabel perilaku PHBS terdiri dari: } \\
\text { 1. } \quad \text { Adanya anggota keluarga yang merokok } \\
\text { 2. Jumlah batang rokok yang dikonsumi setiap hari sebelum pandemi } \\
\text { 3. Jumlah batang rokok yang dikonsumsi setiap hari setelah pandemi } \\
\text { 4. } \\
\text { 5engonsumsi serat (buah dan sayuran) } \\
\text { Aktivitas fisik minimal } 30 \text { menit }\end{array}$ \\
\hline 8 & Pengetahuan & $\begin{array}{l}\text { Variabel pengetahuan banyak ditanyakan mengenai Covid-19 dan cara penularannya. } \\
\text { Variabel ini akan dihitung dan dibagi menjadi } 3 \text { kelompok, yaitu tinggi, sedang, dan rendah } \\
\text { berdasarkan nilai minimum, maksimum dan mean dari variable ini. Variabel ini memiliki } 8 \\
\text { indikator yaitu } \\
\text { (1) Pengetahuan tentang penularan Covid-19, } \\
\text { (2) Larangan makan secara prasmanan, } \\
\text { (3) Protokol sering cuci tangan, } \\
\text { (4) Menggunakan masker saat keluar rumah, } \\
\text { (5) Olahraga rutin, } \\
\text { (6) Mengurangi atau melarang merokok untuk pencegahan Covid-19, } \\
\text { (7) Peningkatan daya tahan tubuh dengan madu dan vitamin; serta } \\
\text { (8) Pengetahuan bahwa penularan Covid-19 kemungkinan kecil melalui udara. } \\
\text { Jika jawaban dari responden benar, poin diberikan adalah } 2 \text { dan jika salah poin yang } \\
\text { diberikan 1. Jumlah total pengetahuan adalah } 16 \text { poin jika responden menjawabnya dengan } \\
\text { benar }\end{array}$ \\
\hline
\end{tabular}

Pengambilan data dari responden ini dilakukan dengan wawancara terstruktur dan instrumen yang digunakan adalah angket. Tim pengabdian memberikan kenang-kenangan atau buah tangan kepada responden yang bersedia mengisi diwawancarai. Buah tangan tersebut adalah sabun cuci dan detergen di mana kedua hal tersebut merupakan salah satu bahan pokok dalam menjaga kebersihan. Unit analisis dalam pengumpulan kuesioner atau angket ini adalah keluarga atau households, sehingga satu angket merupakan pertanyaan mewakili satu keluarga. 


\section{Hasil dan Pembahasan}

Banyak studi mempelajari tentang Covid-19 ini. Tidak hanya di negara-negara sedang berkembang saja, tetapi Covid-19 juga mengganggu di negara maju, seperti Amerika. Seperti penelitian yang dilakukan oleh Kiaghadi et al (2020), menjelaskan bahwa penyebaran virus ini dapat ditanggulangi dengan manajemen kesehatan, terutama dari ketersediaan pelayanan publik bagi pasien Covid-19 sebagai perencanaan yang dapat dilakukan oleh pemerintahan. Dilihat dari jumlah populasi dengan umur rentan diatas 65 tahun, serta jumlah tempat tidur untuk menampung pasien Covid-19 (Kiaghadi, Rifai, and Liaw 2020). Oleh karena itu, perlu identifikasi biodata dan tingkat pengetahuan masyarakat KRB mengenai virus Covid-19 ini. Tabel 1 telah menjelaskan biodata responden yang diwawancarai dan juga tingkat pengetahuan mereka tentang Covid-19. Sebagian besar (67.9) responden yang diwawancarai berusia antara 18 sampai dengan 54 tahun. Dikarenakan buah tangan setelah wawancara adalah detergen dan sabun cuci tangan, maka responden perempuan (66.2) paling banyak yang berminat untuk diwawancarai.

Berdasarkan pengetahuan, nilai minimum dari pengetahuan adalah 11 dan nilai maksimum adalah 16. Rata-rata dari nilai pengetahuan adalah 13.94 atau mendekati 14 . Berdasarkan tiap-tiap indikator, pengetahuan mengenai hubungan rokok dengan Covid-19 adalah paling rendah (58.9). Tidak banyak orang memahami bagaimana Covid-19 dapat memengaruhi perokok di Indonesia. Penelitian dari Cina mendapatkan perokok memiliki risiko terinfeksi SARS-COV-2 14 kali lebih tinggi pada perokok. Dikarenakan perokok merupakan kelompok rentan dengan gejala Covid-19 yang lebih parah dibandingkan bukan perokok, dengan correlation coefficient 0.302 (Chatterjee et al. 2020). SARS-COV-2 menginfeksi sistem pernapasan yang menyebabkan kerusakan ringan hingga parah pada pernapasan. Selain itu, perokok memiliki kesempatan untuk tertular Covid-19 karena saat merokok, jari-jari bersentuhan dengan bibir sehingga transmisi virus dari tangan ke mulut bisa lebih sering terjadi (Theunion.org 2020).

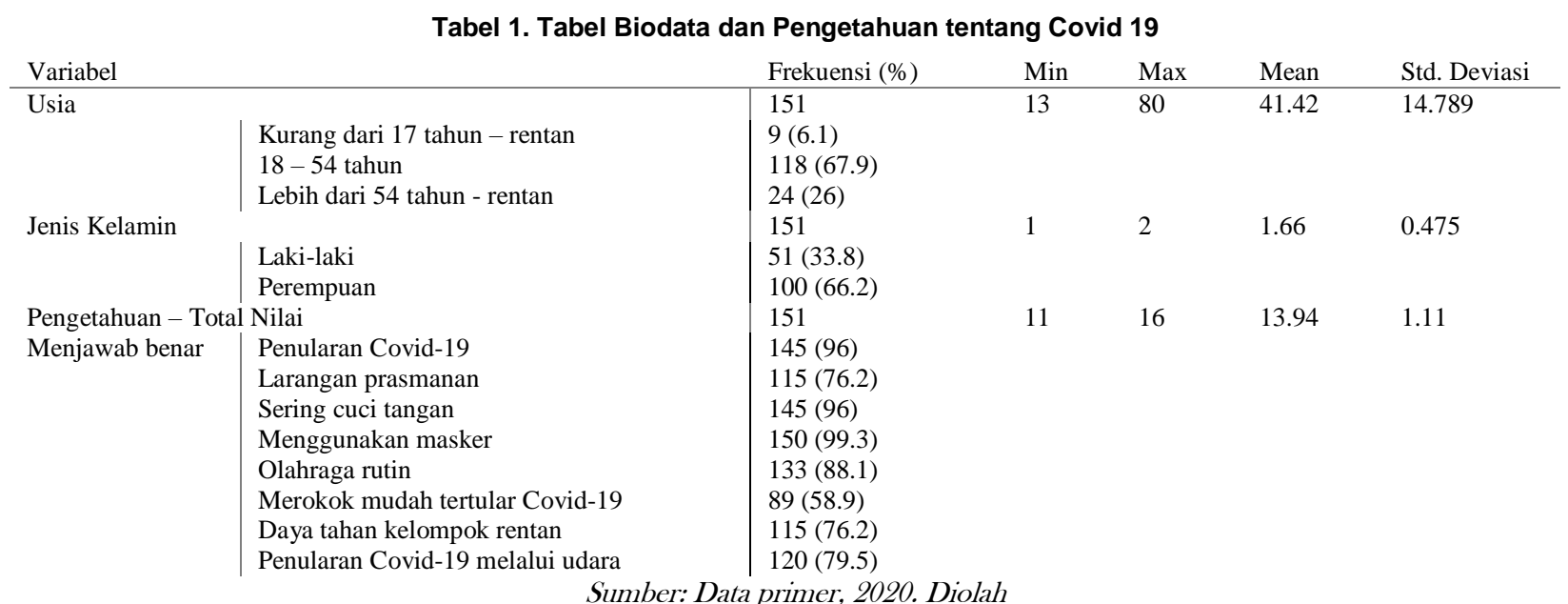

Pengetahuan bahwa penggunaan masker (99.3) merupakan perubahan perilaku yang perlu dilakukan dalam pencegahan penularan Covid-19. Banyaknya paparan informasi bahwa masker merupakan alat yang membantu pencegahan penularan Covid-19 membuat banyak masyarakat sadar dan memahami pentingnya penggunaan masker. Tidak hanya di Indonesia, India menggunakan salah satu alat menghitung risiko penyebaran Covid-19, yaitu dengan aplikasi risk communication dan risk governance. Penilaian preventif atau pencegahan adalah dengan perubahan perilaku masyarakat untuk memutus mata rantai penularan Covid-19, seperti halnya yang sudah diaplikasikan di Jepang dan Korea Sealtan. Komponen penting dalam pencegahan penularan Covid-19 dalam faktor social policy adalah lockdown dan ketaatan 
masyarakat dalam menggunakan masker dan jaga jarak (Chatterjee et al. 2020). Pemahaman bahwa penularan Covid-19 tidak bisa melalui udara dipahami oleh sebanyak $79.5 \%$ responden, yang akhirnya jaga jarak merupakan faktor utama dalam implementasi protokol Kesehatan. Pengetahuan setiap individu merupakan hal yang penting bagi pencegahan penularan secara kluster atau area. Akan tetapi banyak implikasi yang akan terjadi dari pemahaman itu, apakah individu patuh dan mengimplementasikan aksi protokol Kesehatan atau tidak. Oleh karena itu, komunikasi Kesehatan harus relefan dengan setiap aspek yang berhubungan dengan sehat dan sejahtera (Bavel et al. 2020). Untuk melihat apakah pengetahuan dapat mengubah perilaku hidup bersih dan sehat masyarakat Desa Dongkelsari, tabel 2 memaparkan frekuensi data yang diambil dari program pengabdian ini.

Tabel 2. Perilaku Hidup Bersih dan Sehat Masyarakat Desa Dongkelsari

\begin{tabular}{|c|c|c|c|c|c|}
\hline Variabel & Frekuensi (\%) & Min & $\operatorname{Max}$ & Mean & Std. Deviasi \\
\hline Perilaku PHBS - Keluarga Merokok Sebelum Pandemi & 151 & 1 & 2 & 1.5 & .502 \\
\hline Ada anggota merokok & 75 (49.7) & & & & \\
\hline Tidak ada anggota merokok & $76(50.3)$ & & & & \\
\hline Jumlah Rokok sebelum Pandemi & 83 & 0 & 12 & 0.63 & 2.29 \\
\hline 0 & 77 (90.6) & & & & \\
\hline 1 batang & $1(1.2)$ & & & & \\
\hline 2 batang & $1(1.2)$ & & & & \\
\hline 4 batang & $1(1.2)$ & & & & \\
\hline 5 batang & $2(2.4)$ & & & & \\
\hline 6 batang & $1(1.2)$ & & & & \\
\hline 8 batang & $1(1.2)$ & & & & \\
\hline 12 batang & $1(1.2)$ & & & & \\
\hline Perubahan jumlah rokok setelah pandemi & 115 & 1 & 4 & 1,16 & 0.670 \\
\hline Tidak ada perubahan & $109(94.8))$ & & & & \\
\hline Berhenti merokok & $6(5.2)$ & & & & \\
\hline Protokol kesehatan-Cuci tangan & 151 & 1 & 4 & 3.93 & 0.329 \\
\hline Sering & $142(94)$ & & & & \\
\hline Kadang-kadang & $8(5.3)$ & & & & \\
\hline Tidak Pernah & $1(0.7)$ & & & & \\
\hline Protokol kesehatan-Handsanitizer & 151 & 1 & 4 & 3.36 & 0.726 \\
\hline Tidak Pernah & $4(2.6)$ & & & & \\
\hline Jarang & $10(6.6)$ & & & & \\
\hline Karang-kadang & $64(42.4)$ & & & & \\
\hline Sering & $73(48.3)$ & & & & \\
\hline Protokol kesehatan - Jaga jarak & 151 & 1 & 4 & 3.26 & 0.707 \\
\hline Tidak Pernah & $1(0.7)$ & & & & \\
\hline Jarang & $20(13.2)$ & & & & \\
\hline Karang-kadang & 69 (45.7) & & & & \\
\hline Sering & $61(40.4)$ & & & & \\
\hline
\end{tabular}

Perilaku Hidup Sehat dan Bersih yang diintegrasikan dengan pencegahan Covid-19, terlebih lagi di daerah dengan rawan bencana. Salah satu bencana yang diulas oleh Henderson (2020), kebakaran hutan di beberapa negara dapat memperparah pandemi Covid-19. Beberapa negara, salah satunya Australia memiliki bencana musiman yaitu kebakaran atau wildfire. Hal ini perlu diidentifikasi secara spasial dalam kuratif dan preventif, salah satunya identifikasi kebutuhan kamar pasien di beberapa lokasi pelayanan kesehatan (Henderson, 2020). Virus corona menyerang imun manusia dengan menyerang sistem pernapasan dan juga indera perasa. Untuk meningkatkan atau mempertahankan imunitas manusia, diperlukan gaya hidup sehat bagi setiap individu. Gaya hidup sehat dimulai dengan diet, tidak merokok, aktivitas fisik atau olahraga, mengurangi stres, polusi udara, klaster tempat tinggal di pemukiman industri dan status sosio-ekonomi (Buonomo et al. 2020). Salah satu indikator gaya hidup sehat adalah perilaku merokok keluarga di Desa Dongkelsari. Sebanyak 49.7\% menyatakan anggota keluarganya ada yang merokok. Dikarenakan kebiasaan merokok dapat memengaruhi penyakit kardiologi dan endothelial dysfunction - endotelium adalah sejenis sel yang membentuk suatu jaringan dan memisahkan pembuluh darah dan sistem limfatik pada seluruh bagian tubuh - dan Covid-19 memiliki hubungan erat dengan adanya enfothelial dysnfunction. Oleh karena itu, 
perilaku merokok sangat dekat dengan risiko tertularnya Covid-19 (Da Silva, Moreira, and Martins 2020).

Di tim pengabdian mencoba mengidentifikasi, apakah ada perubahan perilaku merokok sebelum dan sesudah pandemi Covid-19. Hal ini ingin diidentifikasi karena selama Covid-19, tekanan stres semakin tinggi. Akan tetapi, sebanyak $94.8 \%$ menyatakan tidak ada perubahan jumlah rokok yang dikonsumsi sebelum dan sesudah pandemi Covid-19. Beberapa protokol kesehatan 3M yaitu mencuci tangan; Menggunakan masker dan Menjaga jarak antar orang sekitar ditanyakan ke keluarga-keluarga yang ada di Desa Dongkelsari. Seringnya cuci tangan (94\%) merupakan protokol kesehatan yang dilakukan oleh masyarakat disana. Akan tetapi, penggunaan handsanitizer $(48.3 \%)$ dan jaga jarak (40.4\%) menjadi protokol kesehatan yang tidak banyak orang sering melakukannya. Social distancing atau jaga jarak dan isolasi mandiri merupakan protokol kesehatan yang diaplikasikan di semua negara (Nicola et al. 2020).

Tabel 3. Implementasi Internal Protokol Kesehatan

Variabel Frekuensi (\%) Min Max Mean Std.

Implementasi Internal Desa Dongkelsari

\begin{tabular}{|c|c|c|c|c|c|}
\hline $\begin{array}{l}\text { Fasilitas tong cuci tangan di } \\
\text { depan rumah }\end{array}$ & $135(89.4)$ & 1 & 3 & 2.85 & .453 \\
\hline Pembatasan tamu luar di desa & $140(92.7)$ & 1 & 3 & 2.89 & .425 \\
\hline Diberlakukannya jam malam & $124(82.1)$ & 1 & 3 & 2.75 & .565 \\
\hline $\begin{array}{l}\text { Melarang } \\
\text { menginap }\end{array}$ & $126(83.4)$ & 1 & 3 & 2.74 & .629 \\
\hline Sistem buka-tutup gerbang & $136(90.1)$ & 1 & 3 & 2.85 & .468 \\
\hline $\begin{array}{l}\text { Isolasi mandiri setelah } \\
\text { bepergian }\end{array}$ & $133(88.1)$ & 1 & 3 & 2.79 & .596 \\
\hline Wajib menggunakan masker & $145(96.0)$ & 1 & 3 & 2.93 & .340 \\
\hline $\begin{array}{l}\text { Melarang mengadakan } \\
\text { hajatan }\end{array}$ & $110(72.8)$ & 1 & 3 & 2.60 & .713 \\
\hline $\begin{array}{l}\text { Ketentuan lapor diri yang } \\
\text { ketat }\end{array}$ & $129(85.4)$ & 1 & 3 & 2.75 & .635 \\
\hline
\end{tabular}

Implementasi protokol kesehatan dibagi menjadi implementasi secara internal atau yang sudah dilaksanakan oleh pihak luar (lihat tabel 3). Protokol kesehatan internal merupakan protokol kesehatan yang dilakukan oleh masing-masing masyarakat unit kecil dan diawasi oleh pimpinan dari masyarakat tersebut. Kewajiban menggunakan masker (96\%) dan pembatasan tamu luar di desa $(92.7 \%)$ merupakan protokol yang ketat di Desa Dongkelsari. Saat pertama kali datang saat pandemi Covid-19 sedang mulai meluas di Indonesia, Kepala Desa Dongkelsari menetapkan protokol yang ketat bagi warga di dalam Dongkelsari. Pengamanan dengan cara pelarangan orang luar masuk ke daerah huntap desa Dongkelsari sebagai pembatasan akses orang luar. Selain itu, mewajibkan semua warga menggunakan masker kain untuk pencegahan penularan Covid-19 di huntap Dongkelsari. Akan tetapi, hajatan (72.8\%) masih banyak dilaksanakan di wilayah ini, misalnya pernikahan dan beberapa hajatan kebudayaan mereka. Fasilitas tong cuci tangan disetiap rumah juga menjadi ketentuan wajib bagi warga desa Dongkelsari.

Implementasi eksternal protokol kesehatan merupakan pengawasan masyarakat huntap Desa Dongkelsari terhadap beberapa lokasi di sekitar wilayah Kabupaten Sleman (lihat tabel 4). Protokol yang diidentifikasi adalah ketersediaan tempat cuci tangan; penyediaan hand-sanitizer dan jaga jarak. Lokasi yang dievaluasi adalah pasar, warung makan, mall, rumah sakit, klinik, puskesmas, supermarket dan sekolah. Berdasarkan ketersediaan tempat cuci tangan, puskesmas (90.0\%) menyediakan tempat cuci tangan. Puskesmas sebagai pelayanan kesehatan adalah 
tempat utama dalam implementasi protokol kesehatan sebagai contoh kepada masyarakat. Begitu juga dengan dua protokol lainnya, yaitu penyediaan handsanitizer $(86.1 \%)$ dan jaga jarak $(91.4 \%)$ telah memberikan contoh implementasi protokol kesehatan 3M.

Tabel 4. Implementasi Eksternal Protokol Kesehatan

Variabel

Frekuensi (\%) Min Max Mean Std.

Implementasi Eksternal tentang Protokol Kesehatan

\begin{tabular}{|l|ccccc} 
Tempat cuci tangan (TCT) & & & & & \\
Pasar & $123(81.5)$ & 1 & 4 & 3.26 & 1.075 \\
Warung makan & $131(86.8)$ & 1 & 4 & 3.46 & .985 \\
Mall & $114(75.5)$ & 1 & 4 & 3.23 & 1.235 \\
Rumah sakit & $131(86.8)$ & 1 & 4 & 3.60 & .939 \\
Klinik & $135(89.4)$ & 1 & 4 & 3.64 & .890 \\
Puskesmas & $136(90.0)$ & 1 & 4 & 3.66 & .864 \\
Supermarket & $124(82.1)$ & 1 & 4 & 3.42 & 1.104 \\
Sekolah & $123(82.1)$ & 1 & 4 & 3.39 & 1.113 \\
Handsanitizer & & 1 & 4 & 2.87 & 1.129 \\
Pasar & $116(70.2)$ & 1 & 4 & 3.19 & 1.029 \\
Warung makan & $125(82.8)$ & 1 & 4 & 3.19 & 1.1287 \\
Mall & $117(77.5)$ & 1 & 4 & 3.48 & 1.045 \\
Rumah sakit & $128(84.8)$ & 1 & 4 & 3.47 & 1.032 \\
Klinik & $130(86.1)$ & 1 & 4 & 3.59 & 1.012 \\
Puskesmas & $131(85.8)$ & 1 & 4 & 3.33 & 1.069 \\
Supermarket & $126(83.4)$ & 1 & 4 & 3.26 & 1.134 \\
Sekolah & $123(81.5)$ & 1 & 4 & 2.82 & 1.071 \\
Jaga Jarak & & 1 & 4 & 3.12 & .945 \\
Pasar & $97(64.3)$ & 1 & 4 & 3.08 & 1.160 \\
Warung makan & $128(84.8)$ & 1 & 4 & 3.64 & .890 \\
Mall & $113(79.0)$ & 1 & 4 & 3.64 & .867 \\
Rumah sakit & $137(90.7)$ & 1 & 4 & 3.65 & .866 \\
Klinik & $138(91.4)$ & 1 & 4 & 3.26 & 1.021 \\
Puskesmas & $138(91.4)$ & 1 & 4 & 3.26 & 1.122 \\
Supermarket & $128(85.9)$ & & & & \\
Sekolah & $123(82.6)$ & & & & \\
\hline
\end{tabular}

Masyarakat Desa Dongkelsari telah sejak awal mengimplementasikan protokol kesehatan 3M yang diinisiasi oleh kepala desa. Kesuksesan tidak hanya dari kepala desa tetapi kesadaran oleh warga dalam mendukung kebijakan-kebijakan yang telah dikeluarkan oleh kepala desa. Dikala pandemi Covid-19 mulai merebak, Gunung Merapi kembali erupsi dengan skala ringan dan sedang dalam kekuatan erupsi nya. Hujan abu ringan sampai lebat juga menjadi salah satu faktor warga Huntap Dongkelsari untuk bisa menggunakan masker tanpa terkecuali.

\section{Simpulan}

Aksi independensi implementasi protokol kesehatan di KRB II Huntap Dongkelsari merupakan salah satu contoh sukses kesadaran masyarakat pencegahan penularan Covid-19. 
Sejak bulan Maret hingga Oktober, tidak ditemukan kasus konfirmasi Covid-19 di huntap Dongkelsari ini. Pengetahuan mengenai penularan dan pencegahan Covid-19 merupakan dasar dari masyarakat sadar dalam mengimplementasikan protokol kesehatan. Kurangnya pengetahuan tentang bahaya rokok yang memengaruhi tingkat keparahan atau penularan Covid19 menjadi salah satu kelemahan yang ada di Huntap Dongkelsari. Covid-19 merupakan krisis atau bencana dengan skala yang besar, sehingga perubahan perilaku merupakan kunci utama dalam penekanan penularan virus ini. Rekomendasi dari epidemiologist dan para ahli kesehatan masyarakat dapat digunakan menjadi cara yang efektif menekan angka konfirmasi di suatu negara (Bavel et al. 2020). Kebiasaan gaya hidup sehat, termasuk salah satunya perilaku merokok dapat memengaruhi sistem imun setiap manusia. Kebiasaan merokok seseorang dipengaruhi dengan status sosio-ekonomi yang rendah, budaya dan perilaku yang menyimpang dalam menjaga kesehatan (Aydemir and Ulusu 2020). Di dalam penelitian ini menghasilkan simpulan bahwa masyarakat masih kurang mengerti bagaimana rokok dapat menjadi faktor risiko yang berbahaya sebagai tempat penularan Covid-19 di lingkungan sekitarnya.

\section{Ucapan Terima Kasih}

Terima kasih diucapkan kepada Kepala Desa Huntap Dongkelsari dan seluruh warga masyarakat di Desa Dongkelsari. Atas kesediaannya dalam pengevaluasian secara wawancara dengan instrumen angket. Tim juga mengucapkan banyak terima kasih kepada Universitas Muhammadiyah Yogyakarta dalam peningkatan kapasitas dan bantuan kepada penduduk di KRB II Gunung Merapi. Tidak lupa, ucapan terima kasih kepada tim yaitu Nabila, Riyanti, Abud dalam pelaksanaan program pengabdian mengenai PHBS menekan penularan Covid-19 di wilayah KRB Gunung Merapi. Terima kasih kami berikan kepada Dinas Kesehatan Kabupaten Sleman dalam membersamai program hibah pengabdian ini, sehingga program ini dapat dilaksanakan dengan lancar.

\section{Daftar Pustaka}

Aydemir, Duygu, and Nuriye Nuray Ulusu. 2020. "Influence of the Life Style Parameters Including Dietary Habit, Chronic Stres and Environmental Faktors and Jobs on the Human Health in Relation to COVID-19 Pandemi." Disaster Medicine and Public Health Preparedness 90 (212): 1-4. https://doi.org/10.1017/dmp.2020.222.

Bavel, Jay J.Van, Katherine Baicker, Paulo S. Boggio, Valerio Capraro, Aleksandra Cichocka, Mina Cikara, Molly J. Crockett, et al. 2020. "Using Social and Behavioural Science to Support COVID-19 Pandemi Response.” Nature Human Behaviour 4 (5): 460-71. https://doi.org/10.1038/s41562-020-0884-z.

Buonomo, Ersilia, Stefania Moramarco, Alessandro Tappa, Sandro Palmieri, Sara Di Michele, Giorgia Biondi, Giulia Agosti, Claudia Alessandroni, Emanuele Caredda, and Leonardo Palombi. 2020. "Access to Health Care, Nutrition and Dietary Habits among School-Age Children Living in Socio-Economic Inequality Contexts: Results from the 'ForGood: Sport Is Well-Being' Programme.” International Journal of Food Sciences and Nutrition 71 (3): 352-61. https://doi.org/10.1080/09637486.2019.1655714.

Chatfield, Akemi Takeoka, Hans J.Jochen Scholl, and Uuf Brajawidagda. 2013. "Tsunami Early Warnings via Twitter in Government: Net-Savvy Citizens' Co-Production of Time-Critical Public Information Services." Government Information Quarterly 30 (4): 377-86. https://doi.org/10.1016/j.giq.2013.05.021. 
Chatterjee, Ranit, Sukhreet Bajwa, Disha Dwivedi, Repaul Kanji, Moniruddin Ahammed, and Rajib Shaw. 2020. "COVID-19 Risk Assessment Tool: Dual Application of Risk Communication and Risk Governance." Progress in Disaster Science 7: 100109. https://doi.org/10.1016/j.pdisas.2020.100109.

Chen, Qiang, Chen Min, Wei Zhang, Ge Wang, Xiaoyue Ma, and Richard Evans. 2020. "Unpacking the Black Box: How to Promote Citizen Engagement through Government Social Media during the COVID-19 Crisis." Computers in Human Behavior 110 (April): 106380. https://doi.org/10.1016/j.chb.2020.106380.

Henderson, Sarah B. 2020. "The COVID-19 Pandemi and Wildfire Smoke: Potentially Concomitant Disasters." American Journal of Public Health 110 (8): e1-3. https://doi.org/10.2105/ajph.2020.305744.

Jernigan, Daniel B. 2020. "Update: Public Health Response to the Coronavirus Disease 2019 Outbreak - United States, February 24, 2020.” MMWR. Morbidity and Mortality Weekly Report 69 (8): 216-19. https://doi.org/10.15585/mmwr.mm6908e1.

Karasneh, Reema, Sayer Al-Azzam, Suhaib Muflih, Ola Soudah, Sahar Hawamdeh, and Yousef Khader. 2020. "Media's Effect on Shaping Knowledge, Awareness Risk Perceptions and Communication Practices of Pandemi COVID-19 among Pharmacists." Research in Social and Administrative Pharmacy, no. April. https://doi.org/10.1016/j.sapharm.2020.04.027.

Kegiatan, Rencana, Rehabilitasi Dan, Rekonstruksi Berdasarkan, Dala Dan, Banjir Lahar, Renaksi Merapi, Rekonstruksi Pasca, Erupsi Gunung, and Merapi Tahun. 2013. "Rencana Kegiatan Rehabilitasi Dan Rekonstruksi 4.1.,"1-23.

Kiaghadi, Amin, Hanadi S Rifai, and Winston Liaw. 2020. "Assessing COVID-19 Risk, Vulnerability and Infection Prevalence in Communities." MedRxiv, 2020.05.03.20089839. https://doi.org/10.1101/2020.05.03.20089839.

Lavell, Allan. 2020. "COVID-19 : Relationships with Disaster Risk, Its Concept and Management Table of Contents," 1-31.

Nicola, Maria, Zaid Alsafi, Catrin Sohrabi, Ahmed Kerwan, Ahmed Al-Jabir, Christos Iosifidis, Maliha Agha, and Riaz Agha. 2020. "The Socio-Economic Implications of the Coronavirus Pandemi (COVID-19): A Review.” International Journal of Surgery 78 (April): 185-93. https://doi.org/10.1016/j.ijsu.2020.04.018.

Shi, Yufang, Ying Wang, Changshun Shao, Jianan Huang, Jianhe Gan, Xiaoping Huang, Enrico Bucci, Mauro Piacentini, Giuseppe Ippolito, and Gerry Melino. 2020. "COVID-19 Infection: The Perspectives on Immune Responses." Cell Death and Differentiation 27 (5): 1451-54. https://doi.org/10.1038/s41418-020-0530-3.

Silva, Andre Luiz Oliveira Da, Josino Costa Moreira, and Stella Regina Martins. 2020. "COVID-19 and Smoking: A High-Risk Association." Cadernos de Saude Publica 36 (5). https://doi.org/10.1590/0102-311X00072020.

Theunion.org. 2020. "Gabungan Yang Berbahaya - Rokok Dan COVID-19 Panggilan Aksi Untuk Pemerintah.” International Union Against Tuberculosis and Lung Disease (The 
UNION), 1-5. https://www.theunion.org/news-centre/covid-19/body/Deadly-PartnersTobacco-and-COVID-19-Bahasa-Indonesia-7-May-2020.pdf.

Velavan, Thirumalaisamy P., and Christian G. Meyer. 2020. "The COVID-19 Epidemic." Tropical Medicine and International Health 25 (3): 278-80. https://doi.org/10.1111/tmi.13383. 